\title{
日本語学習のためのインターネットの利用と問題点について 一中国の大学日本語専攻生を対象に The use and issues of Internet for Japanese language learners: focusing on Japanese major students at a university in China
}

葛茜

福州大学外国語学部日本語学科 早稲田大学日本語教育研究科博士後期課程

\section{要旨}

近年、インターネットの急速な普及と進歩が海外の日本語教育に大きな変化をもたらしている。 インターネットを介して、海外の日本語学習者は日本に関する膨大な量の情報を瞬時にかつ手軽に 入手できるほかに、電子メールや掲示板などのコンテンツを使って自ら情報を発信し、他人と情報 を共有することができるようになってきている。インターネットが秘めている多くの可能性をいか に日本語学習、日本語教育に生かすのか、海外の日本語学習者にとっても、日本語教師にとっても 大きな課題の一つであろう。本研究は、中国某大学の日本語専攻生 52 名を対象に実施したインター ネット利用についての調査を報告する。日本語専攻生はインターネットを介してさまざまなサイト、 コンテンツを利用して日本語を学習していることがわかった。しかし問題点が多く、実際日本語学 習にあまり結びついていないという否定的な評価が多かった。本研究では調査結果を踏まえて学習 者がインターネットを介して日本語学習とじう関わっているかに注目し、インターネットを生かし た日本語学習についても提言する。

キーワード :

インターネット、日本語専攻生、日本語学習総合サイト、学習プロセス 


\title{
日本語学習のためのインターネットの利用と問題点について 一中国の大学日本語専攻生を対象に
}

\author{
葛 茜 \\ 福州大学外国語学部日本語学科 \\ 早稲田大学日本語教育研究科博士後期課程
}

\section{1.はじめに}

近年、インターネットの急速な普及と進歩が海外の日本語教育に大きな変化をもたらしている。 インターネットを介して、海外の日本語学習者は日本に関する膨大な量の情報を瞬時にかつ手軽に 入手できるほかに、電子メールや掲示板などのコンテンツを使って自ら情報を発信し、他人と情報 を共有することができるようになってきている。インターネットが秘めている多くの可能性をいか に日本語学習、日本語教育に生かすのか、海外の日本語学習者にとっても、日本語教師にとっても 大きな課題の一つであろう。近年日本語学習におけるインターネットの利用実態についての調查や、 インターネットを教室活動に活用した実践研究などをよく目にするようになったが、その多くはイ ンターネット上の日本語学習のリソースを整理したもの、あるいは教室内で行なわれた実践的なも のが多くて、実際に学習者は教室外でどのようにインターネットを利用しているか、また日本語学 習とどのように関わっているかについての研究はまだ少ない。本研究は、中国某大学の日本語専攻 生 52 名を対象に実施したインターネットの利用についての調查を報告する。論考は最新の中国にお けるインターネットの事情をまとめた上、日本語専攻生は教室外でどのようにインターネットを利 用しているか、日本語学習との関わりはどうなっているかを分析し、インターネットを生かした日 本語学習について提言をあわせてしたい。

\section{2. 先行研究}

インターネットをどのように日本語教育に生かすか、インターネット環境の特性を紹介した研究 (岡本他 2004) や、インターネットを使った日本語 CALL 教材の開発と実践の研究（川村 2009、深 谷 2006 など）は数多くある。村上（2008）では、インターネットは日本語教育にどのような影響を もたらしているかを、実践例を通して学習環境の視点からまとめた。インターネットは教室習得環 境に自然習得環境を創出することができる一方、自然習得環境に教室習得環境を創出することもで きる。海外の日本語教室にとって、従来制限されがちだった日本語使用の場面はインターネットに よって格段に拡大され、また海外の学習者にとって海外に住んでいることそれ自体が自然習得を制 限するものではなくなった。しかし、大きな可能性をもったインターネットはデメリットも秘めて 
いる。インターネット上の情報の信憑性の問題、またどうやって膨大な情報の中から必要な情報を 選び出すことは学習者にとっても教師にとっても新たな課題である。

一方、実際に日本語学習者はどのようにインターネットを活用して学習に臨んでいるか、またイ ンターネット上どのような日本語学習に役立つリソースがあるか、いち早く注目したのは海外にい る研究者である。これはいままで日本語学習のリソースが限られてきた海外の日本語教育にとって は、インターネットは革命的な手段であるからだろう。中国の日本語教育の現場では、韓（2005） は日本語の学習・研究に役立つウェブサイトを調べて分類した。徐（2005）は大規模なアンケート 調査を行い、中国の大学生のインターネット利用実態を調べた。インターネットの接続環境が制限 されていること、学生のインターネットにおけるリテラシーが久けていることが分かった。梁 （2009）は中国の広州の日本語専攻大学生を対象に、日本語学習におけるインターネット利用の現 状調査を行った。インターネットの利用が日本語専攻生の大学生活に普及し、インターネットを介 した学習はすでに大学生の日本語学習において一定の割合を占めているが、学習の意識、方式、効 果はまだ十分とは言えないと結論づけた。これらの研究は一般の傾向が把握できたものの、学習者 は実際にどのようなプロセスで、また具体的にどのような手順と方法でインターネットを介して日 本語学習をしているか触れず課題として残されている。

\section{3. 中国の最新インターネット事情}

中国互聯網信息センター（CNNIC）の最新調査データ（（2011 年 7 月レポート）によると、2011 年 6 月まで約 4.85 億人の人口がインターネットを利用しており、普及率は $36.2 \%$ に達している。 その内、10 歳から 29 歳までの利用者が一番多くて、全体の $56.8 \%$ を占めている。利用時間は一週 間あたり約 18.7 時間となっている。2011 年 6 月までのアプリケーション利用率は以下のようにな っている。

表 1 アプリケーション利用率（2011 年 6 月データ）

\begin{tabular}{|l|c|c|}
\hline \multicolumn{1}{|c|}{ アプリケーション } & 使用人口 (万人) & 使用率 \\
\hline 検索エンジン & 38606 & $79.6 \%$ \\
\hline インスタントメッセンジャー（IM） & 38509 & $79.4 \%$ \\
\hline ネット音楽 & 38170 & $78.7 \%$ \\
\hline ネットニュース & 36230 & $76.7 \%$ \\
\hline ブログ（個人空間） & 31768 & $65.5 \%$ \\
\hline ネットゲーム & 31137 & $64.2 \%$ \\
\hline ネット動画 & 30119 & $62.1 \%$ \\
\hline メール & 25172 & $51.9 \%$ \\
\hline 交友サイト & 22989 & $47.4 \%$ \\
\hline ネット文学 & 19497 & $40.2 \%$ \\
\hline 中国版ツイター & 19497 & $40.2 \%$ \\
\hline ネットショッピング & 17266 & $35.6 \%$ \\
\hline BBS & 14405 & $29.7 \%$ \\
\hline
\end{tabular}

(中国互聯網信息センター（CNNIC）2011 年 6 月統計レポートを筆者翻訳、引用) 


\section{葛 茜: 日本語学習のためのインターネットの利用と問題点について}

\section{一中国の大学日本語専攻生を対象に}

以上の数值から、中国人のインターネット利用は以下の傾向があると思われる：

（1）検索エンジンの利用は一番の目的

検索エンジンの利用者は約 3.8 億人、使用率は $79.6 \%$ 、インターネット利用の最大な目的は 検索であることが分かる。特に近年各検索エンジン会社が画像検索や動画検索、音楽検索など 一般の民衆の日常生活、娛楽に密着した検索にも大きく力を入れているため、利用率が年々拡 大している。たとえば、中国国内で不動な人気と最大のシェアを有している「百度」

$(\mathrm{Baidu})$ と呼ばれる検索エンジンは、ウェブ検索をはじめ、ニュース、写真、動画、地図、 MP 3 などのカテゴリーを設けて、さまざま情報を手軽に調べられるほか、掲示板などの交流コ ンテンツで直接情報の受信、発信ができて、オンラインにて他人と交流できるようになってい る。

（2）インスタントメッセンジャー（IM）が欠かせないコミュニケーションツールとなっているインス タントメッセンジャーの利用率は検索エンジンに小差をつけられて、メールの使用率より $20 \%$ も回っていることから、一般の民衆にとってもっとも主要なコミュニケーションツール になっていることがうかがえる。IM 用のソフトは最も使われているのが愛称「QQ」と呼ばれ る中国の大手 IT 企業「腾讯」が開発したものである。若者の間では絶大な支持を得られて、 携帯やメール感覚で日常的に使われている。このIM ソフトを使って、自分や友達の状態(接続、 離席、オフライン等)を表示する事ができるほかに、リアルタイムで送受信、ボイスチャット の機能で通話ができる。また、IM の機能のほかに、ブログ、ソーシャル・ネットワーキン グ・サービス（SNS）機能、音楽、動画を再生・管理する、オンラインゲーム、ミニブログな どさまざまな機能がついている。この使い勝手さに魅了される利用者が多くて、常時一億人 1 がオンラインにしていると言われるほど絶対な人気度を持っている。

（3）ネット音楽、ニュース、動画の利用は定着してきている

ネット音楽、ネットニュースの利用率はともに $70 \%$ 以上の高い数值を有して、2007 以来利用 目的の上位 5 位の地位を維持している。これはインターネットの利用者の約 6 割は 10 歳から 29 歳までの若年層であることから容易に想像できるだろう。インターネットが普及されるま で、ニュースを知るための主な手段はラジオやテレビ、新聞だった。しかしこれらのメディア は、政府の管理と規制のもとでフィルターにかけられやすく、また報道できる量も限られてい た。

1 腾讯 2010 年 3 月 5 日に公示した数字である。 http://tech.qq.com/zt/2010/qq100000000/ 
インターネットなら最新のニュースをオンラインで受信できる、事件の展開について追跡もで きる、なによりいままで見る（読む）側だった一般の民衆が身近におきたことをインターネッ 卜を通して報道側にも発信し、報道側に対して意見を述べ情報に参加できることは革命的であ った。従って、ネットで最新のニュースをチェックする習慣は一般の民衆に浸透している。動 画の利用は主に映画などの映像のダウンロード、動画サイトへの投稿である。なぜ中国ではネ ット動画サイトの利用率はこれほど高いなのかふたつの理由が考えられる。一つは中国人の視 聴スタイルによるものである。中国人はテレビ番組を録画してみる習慣はないし、また見逃し た番組はネットで見られるのでその必要もない。そのうえ、テレビ局は視聴率の向上に自作の 番組をネットで再放送することは普通であって、話題性のあるイベンドや、中継などをネット で同時放送するようにして若年層の観客獲得に目がない。ネットで放映され、ダウンロードで きる映画、ドラマなどは著作権に違反していることはよく指摘されているが、近年法的には整 備され、ようやく正常化しつつある。

以上の中国本土ならではのインターネット事情からわかるように、中国の一般の民衆はインター ネットを介して情報を収集、発信し、音楽、動画をダウンロードして楽しみ、また IM を使って他人 と交流している。このような傾向は大学生にも見られて、特に学生の間ではメールより「QQ」とい うIM コンテンツは主要なコミュニケーションツールであると考えられる。実際にどのような日本語 学習のためのインターネット・リソースが存在して、日本語学習にどんな影響を与えているか、こ れらの実態を把握するために筆者は調査を行った。次節から調査の概要及び結果を詳述する。

\section{4. 調査の概要}

\section{1 調査対象者}

本研究の調査対象者は中国某大学に在籍している日本語専攻生 52 名である。内訳は三年生 32 名, 4 年生 20 名（男性 7 名、女性 45 名）である。調查は2009年5月から6月までの 2 月間で行なった。

\section{2 調查方法}

調查は3で紹介したIMコンテンツ「QQ」を介して行った。「QQ」を選しだ理由は、次の二点である。 一つはこのコンテンツは調查対象者の間で普及していて、すでにクラスメンバー専用の「QQ群」 （メンバーコミュニティ）が作り上げており、この「QQ群」を通してクラス全員に一斉に情報の通 達ができると判断した。もう一つは、「QQ群」メールにはメッセージ闌が設けられており、そこに メンバー全員が書き込むことができる。この機能を利用して、メンバーの全員のみならず特定の個 人にも質問、発話ができるとともに、発話の内容は全員に届けられ、情報の共有にも繋がると考え た。具体的な調查手順は下記の通りである。 


\section{葛 茜: 日本語学習のためのインターネットの利用と問題点について}

\section{一中国の大学日本語専攻生を対象に}

(1) アンケート調査

全体の傾向を把握するために、インターネットの利用に関する五つの質問を設けて、QQ 群メ ールでクラス全員に配布した。アンケートの回答は群メールで回収し、回収率は $100 \%$ たった。

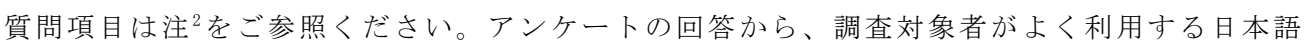
学習のサイトと主な用途がわかった。学習者の回答内容に応じて、筆者はさらにメッセージ欄 で一人一人にフォロアップ・クエスチョンを行ない、回答を回収した。

（2）インタビュー調查

アンケートの内容を踏まえ、より詳細な情報を得るために、5 名の調査対象者を抽出して個別 インタビューを行った。インタビューは全て録音し、調査後文字化をした。

分析の資料は以上の調查方法で得られたアンケートの回答、インタビューの文字化資料、「QQ 群」での書き込みの発言記録である。なお、す心゙ての調査は中国語で行った。

\section{5. 調査結果}

\section{1 インターネットの利用用途と主なサイト}

インターネットの利用の用途として主にあげられたのは「情報検索」、「音楽・動画・画像など のダウンロード・視聴」、「文字チャット、掲示板への書き込み」、「ボイスチャット」である。 これは 3 で紹介した傾向と一致している部分が多い。以下表 2 は調查対象者があげた日本語学習と 関連する主なサイト及び使用用途をまとめたものである。

2 質問は次の五つである。

(1) インターネットはよく利用しますか。頻度と毎回の利用時間を教えてください。

(2) 日本語学習のためによく利用しているインターネット・リソースを挙げてください。利用する 用途も書いてください。

(3) (2)のインターネット・リソースを利用するようになったきっかけは何ですか。利用の方法を具 体的に書いてください。

(4)これらのインターネット・リソースは日本語の学習に役に立ちましたか。なぜですか。

(5)今後どのようにインターネットを活用したいと思いますか。 
表 2 日本語学習サイトと使用用途

\begin{tabular}{|c|c|}
\hline 使用用途 & サイト \\
\hline \multirow[t]{4}{*}{ (1) 聴解 } & http://www. fnn-news.com/ \\
\hline & http://news.tbs.co.jp/ \\
\hline & 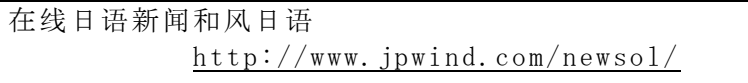 \\
\hline & 中国国際放送局 http://japanese.cri.cn/ \\
\hline \multirow[t]{3}{*}{ (2) 日本語学習総合サイト } & http://japanese.cri.cn/ \\
\hline & http://www. kantsuu.com/ \\
\hline & http://www. jpwind.com/ \\
\hline (3) 検索エンジン & $\begin{array}{ll}\text { Google } & \text { http://www.google.co.jp/ } \\
\text { Yahoo! JAPAN } & \frac{\text { http://www.yahoo.co.jp/ }}{\text { 百度 }}\end{array}$ \\
\hline (4) 映像視聴、ダンロード専用 & $\frac{\text { http://www.tudou.com/ }}{\text { http://www. youku.com/ }}$ \\
\hline (5) 辞書、翻訳専門 & EBW in \\
\hline (6) 掲示板サイト & $\begin{array}{l}\text { Yahoo!掲示板 } \\
2 \text { ちttp://messages.yahoo.co.jp/ } \\
2 \text { hわる }\end{array}$ \\
\hline (7) Q\&A サイト（質問、知識投稿サイト） & Yahoo!知恵袋 http://chiebukuro.yahoo.co.jp/ \\
\hline (8) チャット、ネット電話 & MSN Skype \\
\hline
\end{tabular}

学習者は学習目的に合わせてサイトを選んで利用していることが分かった。聴解能力を向上する ためによく利用したのは日本のニュース番組が視聴できるサイトである。日本のテレビ局のサイト は最も利用されており、理由として「最新のニュースが聞ける」、「発音が正しい」と挙げられた。 しかしアナウンサーの発音のスピードが速くて、また専門用語も多いことから、あまり利用しない 学習者もいた。代わりに選んだのは、「沪江日語」を代表する中国の日本語学習総合サイトにある ニュース番組視聴コーナーである。これらのサイトにアップされたニュース番組の映像の下に字幕 が表示されており、字幕を読みながら聞き間違った、聞き逃した内容がチェックできるので利用す る最大の理由だった。ニュースに出た日本語を説明、解釈する内容まで取り扱うサイトもあった。

検索の場合、学習者は日本語、中国語によって検索エンジンを使い分けている。日本語の場合は $\lceil$ Google 日本」「Yahoo!JAPAN」は最もよく使われる検索エンジンに対して、中国語の場合は「百 度」の利用は圧倒的多い。また、日本語版の「ウィキペディア」、中国版「維基百典」の利用率も 高いことがわかった。

EBWin の辞書、翻訳機能はよく利用されている。特にサイトやブログなどを閲覧している際、分 からない言葉をその場ですぐ調べられるので学習者に好まれているようである。揭示板は名挙げら れたのは日本でも知名度の高い「Yahoo! 掲示板」、「2 チャンネル」である。しかし、書き込みの 言葉の中、2 チャンネルでしか通用しない「業界用語」や、流行語、略語などが多くてよく分からな いと、利用者はそれほど多くなかった。 


\section{葛 茜: 日本語学習のためのインターネットの利用と問題点について}

\section{一中国の大学日本語専攻生を対象に}

「土豆網」、「優酷」をはじめ、中国の動画サイトには大まかな数字しか把握できない世界中の コンテンツ、音楽、映画、アニメ、ニュース、コメディなどが揃っている。試しに利用者数最大と いわれている「土豆網」に「日剧」（日本のドラマ）と入力して検索したら、275776 個の映像、日 劇 2011 年秋季（2011 年秋ドラマ） 8059 個 ${ }^{3}$ などの数字が検索欄にあがってきて、これらの数字か らどれほど膨大な数の映像資料が収納されていることは容易に想像できよう。しかも海外のコンテ ンツにはボランテアにより中国語に翻訳された字幕が入っている。これらの材料はオンラインで視 聴することができる。個人のパソコンにダウンロードして視聴する場合、24 時間以内で削除するよ うに規制されている。当然、学習者はこのような豊富な日本語のリソースを無視できず、ほとんど の調査対象者は動画サイトにアクセスして日本のドラマや映画などを視聴していることが分かった。

ここで特に一筆紹介したいのは中国の日本語学習総合サイトである。

梁（2009）の調查結果と一致している部分があって、最も利用する日本語学習総合サイトとして 「沪江日語」、「贯通日語」、「和风日語」の三つを挙げられた。これらのサイトの大きな特徵は まず使用目的に応じて細分化していることである。例として今回の調査で最も利用率の高い日本語 学習総合サイト「沪江日語」を見てみよう。「入門者向け」、「日本語能力試験」、「聴解」、

「ビジネス日本語」、「番組」、「日本の音楽」、「オンラインラジオ」、「留学案内」など 14 の カテゴリーが設けられて、クリックしたら各カテゴリーに更に細かく分類された内容が取り込まれ ている。メインページには最新のニュース、最新の投稿文の紹介や、著名人のブログの推薦、新刊 図書の紹介などの内容がずっしり詰め込まれ、スクロールしないとページ全体が見えないぐらいた くさんの情報が入っている。

もう一つの特徵は情報の「最新」への拘りである。常に日本側の最新情報を提供することは各サ イトの「売り」かもしれないが、その新しさに感服するほどである。たとえば、「和風日語」は日 本共同通信社の重要なニュースを選んで一日遅い中国語に訳してアップしている。ニュースコーナ ーではNHK ワールドラジオジャパンにリンクして、ほぼ同時にオンラインニュースが聞けるように なっている。

また、日本語学習の内容が多い。例えば、「沪江日語」は入門、初級、中級、上級に分けてレベ ルに応じた学習内容を編集している。「日語考試」（日本語テスト）というコーナーに日本語能力 試験、JTEST（実用日本語検定）の模擬テスト、過去問題集、質疑応答の内容が取り込まれている。 サイト自作のオリジナリティーの日本語学習コラムもたくさんある。「跟小D 学日語」（Dさんにつ いて日本語を学ぼう）という人気度の高いコーナーに「一日一句」というコラムがあるが、例とし て、2011年10月17日の内容を挙げて紹介する。

32011 年 10 月 29 日時点で検索を行って得た数字である。 


\section{0 月 17 日}

春の風に誘われるままに、公園を散歩した。/はるのかぜにさそわれるままに、こうえんをさ んぽした。

【中文解释】任凭春风拂面, 我散步在公园。

【单词及语法解说】描述自己散步的状态时使用。

·ま：听其自然, 顺其自然, 如实。

例：あるがままにする。／就那样听其自然。

・誘う「さそう」 :

(1) 劝诱, 邀请。

例：映画に誘う。／约看电影。

（2）促使，引起，引发。

例：眠りを誘う。／催眠。

本句中誘 为第 1 种意思。

一讲解者: kokin123 查看更多详解》》》》

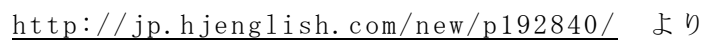

例のように、このコラムは日本語のセンテンスを中国語に訳し、使用例を挙げて単語の意味と文 法の使い方を説明している。なお、サイトには日本人が発音した音声資料もアップされており、ク リックしたら聞けるようになっている。今回の調査対象者のうち、このコラムを頻繁にチェックし て、勉強になったと高く評価する学習者が何人もいた。

またサイト利用者の特徵を配慮した学習内容のものも多くある。たとえば「アニメについて日本 語を学ぼう」、最新のドラマの台詞を使って単語、文型を説明するコラムもあった。日本社会、日 本文化を紹介寸る文章や、在日の中国人学者、ジャーナリストが書いたブログ、日本語教師が書い た日本語の知識、学習要領を収めたコラムはたくさんあった。

上記のように、これらのサイトには, 幅広い分野の情報が含まれており, 同じトピックでも多種 多様なリソースがあって，また、更新のスピードも速いし，学習者は従来の教科書と異なる観点や， 形式から学習ができると思われる。

\section{2 日本語学習との関わりと評価}

では、学習者は実際どのように以上のサイトと利用して日本語を学習しているか、またどのよう に評価しているかを見てみよう。

(1) 聴解用サイトの利用

聴解用サイトを利用する場合、視聴して大体の内容が理解できればいいと思う学習者もいれ ば、視聴しながらメモを取って、分からない単語や文型が出たら音声をストップしてすぐ辞書 を調べる学習者もいた。以下引用のように、聴解サイトは日本語学習に役に立ったと肯定的な 評価が多かった。（引用末尾の記号は調査対象者を識別するもの） 


\section{葛 茜：日本語学習のためのインターネットの利用と問題点について}

\section{一中国の大学日本語専攻生を対象に}

・ニュース番組はいい。日本語の聞き取りの練習にもなったし、最新の日本の情報もわかる。

・FNN はよく使う。音声もあって、映像もある。字幕もあって参照できる。

・日本の TBS のニュース番組はよく使う、映像も原文もあって、内容が新しくて更新も早い。 すごく使いやすい。毎日 30 分ぐらい聞いている。聞きながらメモを取っている。聞くだけ では足りないと思ってね、実用的な、日本語らしい表現、自分だったら出てこない表現や、 単語を書き留めている。（S12）

（2）映像・動画の視聴

日本のアニメやドラマなどをはじめとする日本の大衆文化は海外での認知度が高いことは周 知の通りである。今回の調査対象者のうち、日本のアニメ、日本の芸能事情を熟知する人は多 かった。彼らにとって動画サイトを通して日本のアニメや映画、ドラマなどを視聴することは、 日本語学習のための重要な手段の一つだけではなく、日本の社会、日本文化、日本人の生活な どを知るための有効な方法でもあった。しかし直接日本語の向上に繋がったという印象は薄い ようである。以下は学習者 S5 の興味深い発言を引用する。

・最近はあまり見ないようにしている。というか、物語だけに気を取られて、見て笑って、 終わったら何かが勉強できたかと、全然実感がないんだ。あとはね、中国語の字幕がある から、ついつい見てしまうんだ。確かに、日本人の生活や、日本の文化を理解することは できるけど、日本語がうまくなったということはないと思う。（S5）

個人差があると思うが、ドラマなどの映像コンテンツを利用して、どのように日本語学習の全体 を促進させるかは課題として残されていると言えよう。

（3）日本語学習総合サイトの利用

次に調查対象者S13 の「沪江日語」の利用につての振り返りを紹介する。S13 は「沪江日 語」を利用し始めたのは一年生のときからである。当時まだ日本語を習ったばかりで、最初は サイトにあった能力試験 $3 、 4$ 級模擬テスト問題を解いたり、日本の音楽を聴いたりするぐら いだった。頻繁にアクセスしているうちに、いくつかのコラムに登録し、会員の掲示板を通し てコラムで活躍されている何人かの「日本語の達人」と知り合うことになった。二年生のとき、 「日本語の達人」たちに誘われ、恐る恐る某日本語読解コラムで半年間の編集活動に参加した。 週に三回ネットから日本語の文章を探してきて中国語に訳し、完成したものをサイトにアップ する作業だった。またコラムの会員の質問にも解答しなければならなったので、間違わないよ 
うに一生懸命資料を探したり、分からないとき大学の教師に質問したりしていた。また、日本 のアニメが大好きで、子供のときから声優になりたいという夢があった。日本のアニメの吹き 替えを聞いて日本語に文字化し、さらに中国語に訳してサイトにアップして利用者と分かち合 う、この一連の活動にたいへん満足感を得られたという。S13 のように、サイトを利用する側 からサイト編集・制作側に転身した学習者はそれほど多くないかもしれないが、日本語学習サ イトの情報を受身的に利用するだけではなく、積極的に働きかけることによって新たな活用 の方法が生まれて、言語学習以外の収穫も生まれたことを高く評価できるだろう。また、今回 の調査対象者のほとんどは日本語学習総合サイトを肯定的に評価している。理由は「情報量が 豊富」、「面白い」、「頻繁に更新されている」、「日本語の学習方法も紹介されている」と 説明した。一方、内容があまりにも多すぎで、自分にとってどれがいいかわからないと戸惑う 声もあった。

（4）掲示板とインターネット電話

海外の学習者にとって、直接日本人と日本語で交流する機会はそれほど多くない。また交流 する相手、回数も比較的に限られている（小河原他 2005）。今回の調査で、52 名のうち、イ ンターネットを介して、直接日本人となんらかの交流ができた学習者は 17 人で、半数以下だ ったが、彼らの関わり方にはいっくかの共通点があった。まず手段として使ったのは掲示板と インターネット電話の二つだった。学習者によって若干の違いがあるが、具体的な手順は大体 以下説明するとおりである。

一つは掲示板経由の方法。「Yahoo！掲示板」などの掲示板に入って、興味のあるグループ を見つけたら加入する。話題について揭示板に自分の意見を投稿してみる。また他人の意見を 読んでディスカッションにも参加してみる。話が深まることにつれ、ときどき意気投合になっ た特定の相手が現れてくる。そうしたら 2 人の中のだれかの提案で、 2 人だけのテキストチャ ットをすることになる。ときときボイスチャットまで展開する。

もう一つは利用者の多い無料インターネット電話ツール Skype をダンロードして、「日本 人」、「東京」などのキーワードでユーザ検索をしてみる。上がってきたユーザの個人情報を チェックしてあたりそうな相手にコンタクトに加入したいと申し出のメセッジーを送ってみる。 認可してくれた人に試しに自己紹介して、直接話ができたケースもあれば、拒否され諦めてし まうケースもある。

このようにインターネットを介して、日本人と何らかの形で交流ができたことに、学習者は 「日本人を理解するための一つの空口になっている」、「日本人の若者の考え方がわかる機会 になった」、「日本人のネットフレンドができた」と肯定的に評価している。一方、「よく無 視されている」、「いろんな人がいていい相手を見つけるには難しい」という声もあった。 


\section{葛 茜：日本語学習のためのインターネットの利用と問題点について}

\section{一中国の大学日本語専攻生を対象に}

\section{6. 考察}

上述でわかるように, 学習者は各自のニーズに応じてインターネットを活用している。インター ネット上ではさまざまな日本、日本語、日本語学習と関連するサイトやコンテンツがあって、これ らのものは内容が充実で、情報の更新も早いし、学習者にとって重要な学習のリソースと思われる が、以下の引用のように、否定的に評価している学習者も多くいた。

・インターネットは本当に便利なだけだと思う、日本語の勉強にそんなに役に立ったと思わな い。媒介物にすぎないと思う。確かに何を調べるときはいいかもしれないが、深層的なもの を理解するには難しいと思う。

・ネットにはたしかに学習のリソースがたくさんあるけど、実際に勉強に利用したのは少ない と思う、ネットでくだらないことをチャットして、ドラマやアニメを見ることに費やした時 間は勉強より全然多いと思う。

・確かによく使うけど、効果はそれほど高くない。（S12）

・ネットのリソースは多すぎで雑ですね。情報の量もあまり多すぎる。自分にとってどれがい いか選別することは難しい、漠然としているときが多い。

なぜこのような評価が生まれたか、ここでは学習者がインターネットを利用して学習するプロセ スに注目して分析してみる。

通常、ある学習項目を学ぶ場合、まず記憶して、それから理解して問題を解決し、さらに演習・ 応用を通して、最後に評価するというプロセスがある。このプロセスを通して知識を定着させてい ると考えられている（水口1998）。もし学習者は明確な学習の目的、目標を持たずに、漠然とウェ ブサイトをめぐるだけで、あるいは日本のドラマや映画を視聴する際、物語だけに注意を払うなら、 記憶という段階の前ですでにストップになっていると思われる。李（2006）で「リソースが山ほど あっても学習に取り入れ，生かされない限り真のリソースとはいえない」（p171）と指摘したよう に、インターネットは便利でさまざまな最新情報や知識を提供しているが、もし実際の日本語学習 に取り入れ活用されないと、インターネット上のリソースは単なる情報源に過ぎない。また、日本 語総合学習サイトの場合、たとえ学習者は明確な学習目的を持って、日本語コラムにある単語や、 文法説明を記憶して理解したとしても、学習の過程は完了したわけではない。記憶して理解した知 識を使って、なんらかの課題を遂行して知識を応用し、最後に自分の学習過程を振り返って、学習 成果を評価するという過程の検証を行わないと本当の学習になったとは言えない。 
上述の問題を解決してより効果的にインターネットを活用するには、学習者はサイトにアクセス する際、たとえ日本文化を理解したいという漠然とした学習目的を持つ場合でも、詳細な学習目標 や学習プランを立てれば効果が違ってくると思われる。なぜなら、学習目標があれば、それを達成 するために，適切なサイトやコンテンツを自ら取捨選択をしなければならない。そうすると必要な 情報の性質と範疇を見定めることになる。学習プランを立てば、情報を記憶して理解することだけ で終わるではなく、これらの情報を応用できる課題に取り込み、また、課題を遂行する過程の中で 情報を評価することもできるだろう。こうすることによって、情報をうのみにするではなく、「批 判的」な目を養うことができるだろう。言い換えれば、記憶して理解した学習内容をどうやって応 用、評価をすることによって定着させていくには、知識を応用するための課題を設定することは重 要なステップになっている。学習者自身も教師も積極的に課題を設定すべきだと思われる。学習者 はネットで投稿やブログなどの情報発信の形式で受容した知識を産出し、他人の回答や、評価をチ エックすることで自らの学習成果を評価することができる。一方、教師は学習者が教室外でどのよ うにインターネットを介して日本語学習しているかを把握し、インターネットを活用してどの段階 でどのような教室活動に取り入れるかを考えなければならない。

学習者を教室、教材から解放すべきと叫ばれている今、インターネットの利用は大きな意義があ ると思われる。洪水のようなインターネットの情報から日本語学習に適するものを選択することは、 学習者にとって非常に困難なことで今回の調查で示した通りであるが、教師がどのように学習者の

「情報リテラシー」を育成するかは大きな課題として残されている。

本研究ではコンテンツ「QQ」を介してのアンケート調查を採用した。調查対象者全員が加入して いる「QQ 群」のメールにアンケートを一斎に配布して、アンケートの回収も群メールで行い効率が 高く $100 \%$ の回収率が得られた。また、「QQ 群」メールの書き込み用のメッセージ欄を利用して、 一般のアンケートが困難とされる追加調查もできた。さらに、調查期間中に、「QQ 群」を通して、 調查者と調查対象者、調查対象者の間に活発なインターアクションができた。当然、「QQ」を介し て調查する場合、「QQ 群」に加入することは前提条件とされる。また回答や書き込みの内容は参加 者全員の共有寸るものになるので、匿名アンケート調查には不適合な部分があると思われる。

\section{7. おわりに}

本研究は, 中国の日本語学習のためのインターネットの利用状況をアンケート調査を通して考察 した。学習者はインターネットを介してさまざまなサイト、コンテンツを利用して日本語を学習し ていることがわかった。問題点は多くて、実際日本語学習にあまり結びついていないという否定的 な評価が多かった。今後, 問題点を踏まえて、インターネットを生かした日本語教育の在り方を実 践研究を通して検討していきたい。 
葛 茜: 日本語学習のためのインターネットの利用と問題点について

一中国の大学日本語専攻生を対象に

\section{参考文献}

深谷優子（2006）「メディアを活用した授業」『授業研究と談話分析』秋田喜代美編 $151-159$ 放送大学

韓新紅（2005）「充分利用網絡資源学習和研究日語」『日語学習与研究』2005（4），47-50

李徳奉（2006）「日本語教育を活かすためのリソース・リテラシー」『日本語教育の学習環境と学

習手段にする調查研究一海外調查の成果と展望』22-25 国立国語研究所

川村よし子（2009）「インターネットと日本語教育」『日本語学 特集日本語教育の最新トピック

(1)』8vo128-10,34-45

小河原義郎・金田智子・笠井淳子（2005）「海外における日本語学習者の学習環境と学習手段」

『日本語科学』 $18,111-123$

梁燕碧（2009）「日本語学習におけるインターネット利用の現状調査一広州の日本語専攻大学生を

対象に」『グローバル化社会の日本語教育と日本文化一日本語教育スタンダードと多文化共生リ

テラシー』萬美保・村上史展編 $137-152$ ひつじ書房

水口誠司・柏原昭博・豊田順一（1998）「インターネットにおける学習資源の適応的選択による自

習支援」『信学技報』ET98-105, 97-104

村上京子（2008）「ITを日本語教育に生かす」『多様化する言語習得環境とこれからの日本語教

育』坂本正他編著 214-234 スリーエーネットワーク

岡本敏雄他編著（2004）『e ラーニングの理論と実践一システム技術から、教え・学び、ビジネス

との統合まで』丸善

中国互聯網信息中心（CNNIC）（2011）「第28 次中国互联网络发展状况统计报告」

http://www.cnnic.net.cn/dtygg/dtgg/201107/t20110719_22132.htm1（2011年10月 11 日 アクセス)

陶一智（2010）「中国の最新インターネット事情」

http://wbb.forum. impressrd.jp/feature/20110131/829 (2011 年10月5日アクセス)

トムソン・木下千尋 (1997)「海外の日本語教育におけるリソースの活用」『世界の日本語教育』7, $17-29$

徐紅彩（2005）「在校大学生網絡学習行為的調査与研究」『電化教育研究』6, 61-63 